\title{
Feeding habits, sexual dimorphism and size at maturity of the lizard Cnemidophorus ocellifer (Spix, 1825) (Teiidae) in a reforested restinga habitat in Northeastern Brazil
}

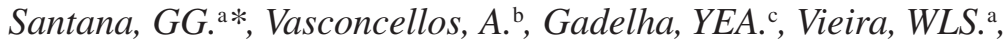 \\ Almeida, WO. ${ }^{\mathrm{d}}$, Nóbrega, $R P^{\mathrm{a}}{ }^{\text {and Alves, } R R N .}{ }^{\mathrm{e}}$
}

aPrograma de Pós-Graduação em Ciências Biológicas (Zoologia), Centro de Ciências Exatas e da Natureza, Laboratório/ Coleção de Herpetologia, Departamento de Sistemática e Ecologia, Universidade Federal da Paraíba - UFPB, CEP 58051-900, João Pessoa, PB, Brazil

bepartamento de Botânica, Ecologia e Zoologia, Universidade Federal do Rio Grande do Norte - UFRN, CEP 59072-970, Natal, RN, Brazil

'Laboratório de Entomologia, Departamento de Sistemática e Ecologia, Centro de Ciências Exatas e da Natureza, Universidade Federal da Paraíba - UFPB, CEP 58051-900, João Pessoa, PB, Brazil

${ }^{d}$ Departamento de Química Biológica, Universidade Regional do Cariri - URCA, Rua Cel. Antônio Luiz, 1161, CEP 63105-000, Crato, CE, Brazil

eDepartamento de Biologia, Universidade Estadual da Paraíba - UEPB,

Av. das Baraúnas, 351, Campus Universitário, Bodocongó, CEP 58109-753, Campina Grande, PB, Brazil

*e-mail: gindomar@yahoo.com.br

Received December 2, 2008 - Accepted April 13, 2009 - Distributed May 31, 2010

\begin{abstract}
The feeding habits, the sexual dimorphism in size and sexual maturity of the actively foraging lizard Cnemidophorus ocellifer were analysed in an area of a reforested Restinga habitat located in the municipality of Mataraca, along the northern-most coast of Paraíba State, Brazil. Seventy-five specimens of C. ocellifer were examined (46 males and 29 females). Of this total, only 23 specimens had prey in their stomachs. The most frequent prey consumed items were orthopterans (50\%), coleopterans (23.9\%) and arachnids (10.9\%); termites and insect larvae were less consumed (both with 2.2\%). There were no significant differences observed between the numbers of prey consumed by either males or females. There were significant differences in SVL (snout-vent length) between the sexes, with males attaining larger SVL values. When the influence of SVL was removed from the analyses, sexual dimorphism in the form was still reflected in the head size of these lizards. Sexual maturity in females and males was attained with SVL of 42.2 and $49.0 \mathrm{~mm}$ respectively. Although no significant difference was observed between the SVL of the females and the number of eggs produced, there was a clear tendency for larger females to produce more eggs. The low structural complexity of the vegetation and the poor soil quality in the reforested restinga area examined does not furnish favourable habitat for insect and termite larvae, contributing to the marked differences in the diet of the population of C. ocellifer observed in the present study in relation to the diet of their conspecifics in undisturbed areas of restinga, cerrado and caatinga.
\end{abstract}

Keywords: diet, lizards, sexual dimorphism in form, clutch size, Atlantic Forest.

\section{Hábito alimentar, dimorfismo sexual e tamanho na maturidade sexual do lagarto Cnemidophorus ocellifer (Spix, 1825) (Teiidae) em restinga reflorestada no Nordeste do Brasil}

\begin{abstract}
Resumo
O hábito alimentar, dimorfismo sexual e tamanho na maturidade sexual do lagarto forrageador ativo Cnemidophorus ocellifer foram analisados em um habitat de restinga reflorestada, situado no município de Mataraca, extremo norte do litoral do Estado da Paraíba, Brasil. Foram examinados 75 espécimes de C. ocellifer, sendo 46 machos e 29 fêmeas. Deste total, apenas 23 espécimes continham presas em seus estômagos. As mais frequentes presas consumidas foram os ortópteros (50\%), coleópteros $(23,9 \%)$ e aracnídeos (10,9\%); enquanto térmitas e larvas de insetos foram os itens menos consumidos (ambos com 2,2\%). Não houve diferença significativa no número de presas consumidas por machos e fêmeas. Houve diferença significativa do SVL (comprimento rostro-cloacal) entre os sexos, com machos alcançando valores máximos de SVL. Removido o efeito do SVL das análises, o dimorfismo sexual na forma foi
\end{abstract}


evidenciado pelo tamanho da cabeça dos lagartos. A maturidade sexual das fêmeas e machos foi alcançada com SVL de 42,2 e 49,0 mm, respectivamente. Embora não tenha havido uma diferença significativa entre o SVL da fêmea e o tamanho de sua desova, foi observada uma clara tendência de fêmeas maiores produzirem desovas maiores. Na área de restinga reflorestada, a baixa complexidade da estrutura da vegetação e inadequada qualidade do solo, provavelmente, não propiciam condições favoráveis de habitat para larvas de insetos e térmitas, desse modo, contribuindo para a marcante diferença na dieta da população de $C$. ocellifer observada no presente estudo em relação a outras áreas de restinga não perturbadas, cerrado e caatinga.

Palavras-chave: dieta, lagartos, dimorfismo sexual na forma, tamanho da desova, Mata Atlântica.

\section{Introduction}

The diets of lizard populations of the same species will be expected to vary over its distribution gradient in terms of their composition and/or the proportions of the different types of prey taken due to local variations in food resource availability (Pianka, 1970; Vitt and Colli, 1994; Vitt, 1995; Vitt et al., 1997; Mesquita and Colli, 2003). These variations in food resources can be caused by differences in the structural complexity of the vegetation that is linked to the local climate (Milstead, 1965; Tauber and Tauber, 1981; Wolda, 1988; Magnusson and Silva, 1993; Shepard, 2007).

Teiidae lizards of the genus Cnemidophorus are typical active foragers (as are the other members of this family) that are commonly encountered in areas of restinga vegetation (Brazilian coastal sand dune habitats that are part of the Atlantic Rainforest biome sensu Suguio and Tesller, 1984) situated along the Brazilian coast. Studies of the feeding habits of populations of this genus indicate the existence of variations in both the composition and the proportions of arthropod groups taken, although termites and insect larvae usually predominate in their stomach contents (Bergallo and Rocha, 1994; Teixeira-Filho et al., 2003; Menezes et al., 2006; Dias and Rocha, 2007).

Studies about the eating habits of lizards in restinga areas in Brazil are relatively rare, and those that have been published are concentrated in the southeastern region of the country (Bergallo and Rocha, 1994; Vrcibradic and Rocha, 1996; Teixeira-Filho et al., 2003; Menezes et al., 2006). There is only incipient information available about the dietary habits of lizards found in similar habitats in restinga areas in northeastern Brazil (Dias and Rocha, 2007).

Studies concerning the ecology of Cnemidophorus species in undisturbed restinga habitats have not generally provided detailed information about the morphological differences between males and females (usually being restricted to snout-vent length measurements), and there is a notable lack of data concerning lizard size at sexual maturity as well as egg clutch size (Teixeira-Filho et al., 2003; Menezes et al., 2004). The most complete descriptions of these characters have been published for populations of Cnemidophorus ocellifer (Spix, 1825). from caatinga dryland areas (Vitt, 1983, 1995), cer-

rado (savanna) (Anderson and Vitt, 1990; Vitt, 1991; Mesquita and Colli, 2002, 2003) and cerrado enclaves in the Amazon Forest (Vitt and Carvalho, 1995).

The present study examined the dietary habits, sexual dimorphism in the form and size at sexual maturity, and size clutch produced by the lizard Cnemidophorus ocellifer in a reforested restinga habitat along the northern shore of Paraíba State in northeastern Brazil by: i) examining the composition of their diet; ii) determining the amount of prey consumed by males and females; iii) determining if the predominance of termites and larvae that have been reported as making up the diet of populations of C. ocellifer living in natural restinga areas (e. g., Bergallo and Rocha, 1994; Teixeira-Filho et al., 2003; Dias and Rocha, 2007) is maintained in an area of reforested restinga vegetation; iv) estimating the minimum body size of males and females when they reach sexual maturity; v) determining if egg production varies in relation to the snout-vent length or body mass of the females.

\section{Materials and Methods}

\subsection{Origin of the specimens examined}

The specimens of $C$. ocellifer examined in the present work make up part of the herpetological collection of the Department of Systematics and Ecology of the Universidade Federal da Paraíba - UFPB, in João Pessoa, Paraiba State, Brazil (see Appendix). The specimens had been collected in an area of reforested restinga vegetation situated slightly south of the Guaju River estuary (6 $6^{\circ} 29^{\prime} 27^{\prime \prime} \mathrm{S}$ and $\left.34^{\circ} 58^{\prime} 03^{\prime \prime} \mathrm{W}\right)$ inside an area owned by a mining company ( $6^{\circ} 32^{\prime} 40^{\prime \prime} \mathrm{S}$ and $\left.34^{\circ} 57^{\prime} 58^{\prime \prime} \mathrm{W}\right)$, within the municipality of Mataraca, along the northern coast of Paraiba State, northeastern Brazil. During mining, all of the vegetation is removed and the underlying sand is processed to extract heavy minerals such as ilmenite, zirconite and rutile. A post-mining restoration plan was initiated in 1988 and comprises five stages: (a) re-establishment of the dune topography, (b) top soil recomposition $(20-30 \mathrm{~cm})$, (c) fertilisation, (d) planting and sowing grass, and (e) control of pests and exotic species (Rosado, 2001; Zeppelini et al., 2008). There are also remnant areas of intact restinga forest on the mining property whose floristic composition was previ- 
ously studied by Oliveira-Filho and Carvalho (1993) and Rosado (2001).

According to collection records, the lizards were harvested during the months of November and December/2005 (dry season) using interception and pitfall traps installed in restinga areas that had been reforested two, four, or eight years earlier. The lizards were anesthetised, sacrificed with a lethal injection of $10 \%$ formalin, and then preserved in $70 \%$ alcohol as soon as the collector returned to the support base installed in the study area.

The regional climate is tropical and rainy, with a short dry season (type Am the Köppen system). The mean annual rainfall in 2006 was $1,246 \mathrm{~mm}$ (Zeppelini et al., 2008), with the most rainfall occurring between the months of April to July; the driest month was December. The average annual temperature is $26.0{ }^{\circ} \mathrm{C}$ and the monthly averages range from $23.7^{\circ} \mathrm{C}$ in April to $27.2^{\circ} \mathrm{C}$ in November (Rosado, 2001).

\subsection{Diet}

The stomachs were removed from the lizards and their contents analysed. The numbers of lizards with empty stomachs was also noted. Each type of prey was identified principally to the level of order after examination under a stereoscopic microscope. The maximum length and width of any intact prey consumed by the lizards was measured using a millimetre scale eyepiece on the stereoscopic microscope. The square root of the product resulting from multiplying the maximum prey length times its maximum width was used as an index of the "standard prey length" (Magnusson et al., 1987). However, as the amount of intact prey encountered was very low $(\mathrm{N}=8)$, it was not possible to determine any relationship between the average standard prey length and the SVL of the lizards. The volume of each prey was estimated using the ellipsoid Equation (1) (Magnusson et al., 2003):

$\mathrm{V}=3 / 4 \times \pi \times \mathrm{L} / 2 \times 2(\mathrm{~W} / 2)^{2}$

where $\mathrm{L}=$ length and $\mathrm{W}=$ width.

We also calculated occurrence (the percentage of stomachs containing a given category of prey) and the numerical and volumetric percentages of each prey category. In order to determine the contribution of each prey category in the diet of these lizards, we calculated their importance index ( $\mathrm{I}_{\mathrm{x}}$ ) (Powell et al., 1990) using the Equation (2):

$I_{x}=(N \%+V \%+F \%) / 3$

calculated as the sum of the numerical, volumetric, and frequency of occurrence percentages divided by three.

\subsection{Morphology and sexual maturity}

In order to test for morphological differences between the sexes of the lizards, we measured the snoutvent length (SVL), head length (HL) from the tip of the snout to the posterior margin the ear opening, head width (HW) at the widest point of the head, and head height $(\mathrm{HH})$ at the thickest portion of the head, using a digital caliper (precision: $\pm 0.01 \mathrm{~mm}$ ); the body mass of each individual was also determined. The comparisons of SVLs between the sexes were based on the $t$-test after verifying the variance homogeneity of data using Levene's test. Other morphological comparisons were made by ANOVA on residuals of $\log _{10}$ SVL for each respective morphological character so that characters could be compared with the bias of size removed. The sexual maturity of the females was estimated based on the SVL of the smallest female within the population that had eggs in its oviduct or vitelogenic follicles. Males were considered sexually mature if they contained both dilated testicules and convoluted epididymides (Anderson and Vitt, 1990; Vitt, 1991).

\section{Results}

\subsection{Diet}

Seventy-five specimens of $C$. ocellifer were examined, including 46 males (SVL: $\bar{x}=58.36 \pm 1.05 \mathrm{~mm}$; range: $45.80-82.40 \mathrm{~mm})$ and 29 females (SVL: $\bar{x}=55.47 \pm 1.08 \mathrm{~mm}$; range: $42.38-67.0 \mathrm{~mm}$ ). Of this total, only $23(30.7 \%)$ had any prey in their stomachs $(\mathrm{N}=46 ; \overline{\mathrm{x}}=2 \pm 1.7 \mathrm{prey} / \mathrm{stomach})$, while $52(69.3 \%)$ had empty stomachs. There was no significant difference between the proportion of males (29/46; $63 \%)$ or females $(23 / 29 ; 79.3 \%)$ with empty stomachs $\left(\mathrm{X}^{2}=2.21 ; \mathrm{P}=0.13\right)$.

The diet of the teiidae $C$. ocellifer was found to be composed of seven categories of dietary items, all of which were arthropods (as shown in Table 1). The order Orthoptera was the most frequently encountered, being present in $50.2 \%$ of the lizard stomachs (and corresponded to $50.0 \%$ of the total prey ingested and $45.4 \%$ of the total prey volume). The second most frequent dietary item was composed of Coleopterans (being present in $26.1 \%$ of the stomachs examined and corresponding to $23.9 \%$ of the total ingested prey and $24.6 \%$ of its total volume). The dietary importance index identified Orthopterans as being the most important item food item $\left(I_{x}=49.2\right)$, followed by Coleopterans $\left(I_{x}=24.9\right)$ and Araneae $\left(I_{x}=15.5\right)$ (as shown in Table 1 ). There was no significant difference observed between the numbers of prey captured by males or females (Mann-Whitney $\mathrm{U}$-test $=50.50, \mathrm{Z}=-0.03, \mathrm{P}=0.97)$.

\subsection{Body of size, sexual dimorphism and egg production}

Of the 75 specimens of Cnemidophorus ocellifer examined, two were young immature males (with SVLs of 45.80 and $48.0 \mathrm{~mm}$ ), 44 were sexually mature males (SVL: $\bar{x}=58.88 \pm 1.03 \mathrm{~mm}$; range: $49.00-82.40 \mathrm{~mm}$ ), and 29 mature females (SVL: $\bar{x}=55.47 \pm 1.08 \mathrm{~mm}$; range: $42.38-67.0 \mathrm{~mm}$ ). The SVL averages of the males and sexually mature females differed significantly, and there were discernable differences in body mass between 
Table 1. Absolute values and percentages of the number, volume $\left(\mathrm{mm}^{3}\right)$, occurrence frequency, and importance index $\left(\mathrm{I}_{\mathrm{x}}\right)$ of each prey category in the diet of Cnemidophorus ocellifer $(\mathrm{N}=23)$ in an area of reforested restinga vegetation (Municipality of Mataraca, northern coast of Paraíba State, northeastern Brazil).

\begin{tabular}{lcrcc}
\hline \multicolumn{1}{c}{ Item consumed } & Number $(\boldsymbol{\%})$ & Volume (\%) & Frequency (\%) & $\mathbf{I}_{\mathbf{x}}$ \\
\hline INSECTA & & & & \\
Orthoptera & $23(50.0)$ & $176.17(45.4)$ & $12(52.2)$ & 49.2 \\
Coleoptera & $11(23.9)$ & $95.3(24.6)$ & $6(26.1)$ & 24.9 \\
Hymenoptera & & & & 5.1 \\
Formicidae & $2(4.3)$ & $26.10(6.7)$ & $1(4.3)$ & 2.4 \\
Isoptera & $1(2.2)$ & $2.34(0.6)$ & $1(4.3)$ & \\
$\quad$ Larva & $1(2.2)$ & & $1(4.3)$ & \\
$\quad$ undetermined) & $3(6.5)$ & & $3(13.0)$ & \\
CHELICERATA & & & $3(13.0)$ & \\
$\quad$ Araneae & $5(10.9)$ & $88.08(22.7)$ & & \\
\hline Total & $46(100 \%)$ & 387.99 & & \\
\hline
\end{tabular}

the two sexes (as shown in Table 2). Males attained a maximum SVL greater than the females, and when the effect of SVL was removed from the analysis, sexual dimorphism was also noted in terms of size head (length, width, and height) (as shown in Table 2).

All of the females examined were sexually mature. The smallest female with eggs in its oviduct and/or vitelogenic follicles had a SVL of $42.38 \mathrm{~mm}$ (considered here as the estimated minimum size for sexual maturity) and a body mass of $1.94 \mathrm{~g}$ (as shown in Table 2). As the number of females with eggs in their oviducts was small, egg production was calculated based on the total number of eggs in the oviducts and vitelogenic follicles. Calculated in that manner, the average production was $5.31 \pm 0.41(1-10 ; \mathrm{N}=154)$ eggs. No significant relationship was observed between the SVL of the females and egg production $(\mathrm{N}=29 ; \mathrm{r}=0.13 ; \mathrm{P}=0.50)$; nor any significant relationship between egg production and the body mass of the females $(\mathrm{N}=29 ; \mathrm{r}=0.08 ; \mathrm{P}=0.68)$. Of the total number of females examined, eight (27.6\%) had eggs in their oviducts $(\mathrm{N}=14$; range: $0-2)$, while $26(72.4 \%)$ had dilated vitelogenic follicles (range: $0-10)$, and five (17.2\%) showed both conditions.

Among the males, the smallest individual with dilated testicules and epididymides convolute had a SVL of $49 \mathrm{~mm}$ (considered here as the estimated minimum size at sexual maturity) and a body mass of $5.86 \mathrm{~g}$.

\section{Discussion}

The population of Cnemidophorus ocellifer examined in the present study demonstrated a generalist arthropodivorous diet type, predominately consuming orthopterans and coleopterans. Termites and insect larvae were consumed in very reduced amounts, quite different from reports of the diets of other populations of this teiidae and of other congeneric species living in restinga (Bergallo and Rocha, 1994; Teixeira-Filho et al., 2003; Menezes et al., 2006; Dias and Rocha, 2007), cerrado (Vitt, 1991; Mesquita and Colli, 2002, 2003), and caatinga areas (Vanzolini et al., 1980; Vitt, 1995), or in enclaves of cerrado in the Amazon Forest (Vitt and Carvalho, 1995).

Variations were expected in the taxa and types of prey consumed by populations of $C$. ocellifer occupying restinga areas along the Brazilian coast, as the structural complexity of the vegetation in different localities, for example, will affect the arthropod fauna composition (Dias and Rocha, 2007). Other important variables were involved in the present study, however, such as the fact that the population of $C$. ocellifer examined inhabits an area of reforested restinga where the floral complexity and the composition/properties of the soil (which was altered by mining and restoration efforts) do not appear to offer habitat conditions adequate for the development of the larval phase of various insect groups (such as lepidopterans and coleopterans) or for assemblies of termites. These observations are in agreement with reports published by Milstead (1965), who observed that insect larvae abundance is directly related to the density of the vegetation cover, as plants help maintain mesic environmental conditions. Additionally, Lee and Wood (1971) observed that sandy soils generally provide poor stability for underground tunnels and nests built by termites, and these insects tend to inhabit soils with higher clay contents. Another strong indication of the low habitatquality of these reforested restinga areas was reported by Zeppelini et al. (2008), who observed that there was a very reduced diversity of collembolan species in areas that had been reforested only two, four, or eight years earlier (although diversity was seen to be greater in areas recuperating for sixteen years). The sixteen year-old areas, nonetheless, still demonstrated collembolan diversity that was significantly reduced in comparison to control areas (preserved restinga).

The explanations offered here for the dietary differences of $C$. ocellifer in the study area are also supported 
Table 2. Comparison of morphometric characters between sexually mature male and female specimens of the lizard Cnemidophorus ocellifer inhabiting an area of reforested restinga vegetation (Municipality of Mataraca, northern coast of Paraíba State, northeastern Brazil). All length units are in millimetres and body mass in grammes; $\mathrm{N}=$ number of lizards measured.

\begin{tabular}{|c|c|c|c|c|c|}
\hline \multirow{2}{*}{ Variable } & \multicolumn{2}{|c|}{ Males $(N=44)$} & \multicolumn{2}{|c|}{ Females $(\mathrm{N}=29)$} & \multirow{2}{*}{$\begin{array}{c}\text { Test of } \\
\text { significance }\end{array}$} \\
\hline & Mean $\pm \mathbf{S E}$ & Range & Mean \pm SE & Range & \\
\hline Snout-vent length & $58.88 \pm 1.03$ & $49.00-82.40$ & $55.47 \pm 1.08$ & $42.38-67.00$ & $t$-test $=-2.24 ; \mathrm{df}=71 ; \mathrm{P}<0.05$ \\
\hline Body mass & $5.28 \pm 0.32$ & $2.84-13.56$ & $4.46 \pm 0.23$ & $1.94-6.43$ & $\mathrm{~F}_{(1.71)}=0.51 ; \mathrm{P}=0.47$ \\
\hline Head length & $16.71 \pm 0.17$ & $14.22-23.00$ & $15.31 \pm 0.21$ & $12.96-17.74$ & $\mathrm{~F}_{(1.71)}=36.07 ; \mathrm{P}<0.001$ \\
\hline Head width & $8.85 \pm 0.16$ & $7.00-12.72$ & $7.96 \pm 0.12$ & $6.52-9.30$ & $\mathrm{~F}_{(1.71)}=25.07 ; \mathrm{P}<0.001$ \\
\hline Head height & $7.84 \pm 0.17$ & $5.86-11.73$ & $6.93 \pm 0.11$ & $5.37-8.16$ & $\mathrm{~F}_{(1.71)}=23.41 ; \mathrm{P}<0.001$ \\
\hline
\end{tabular}

by Vasconcellos et al. (2005), who reported low species richness and relative abundance of termites in remnant areas of preserved restinga situated near the reforested areas, especially in terms of representatives of the subfamily Apicotermitinae and soil-feeders (a majority of which are soil dwellers). If a low species richness of termites was seen in preserved restinga habitats (where there are only low concentrations of organic material and a reduced capacity to retain soil humidity; see Araujo and Lacerda, 1987), it would seem obvious that the restrictive effect of this environment on termites would be even more severe in more recently reforested restinga sites.

It is also necessary to consider the fact that as the dry season advances the availability of insect larvae rapidly diminishes (Pianka, 1970) - which would result in significant effects on the dietary composition of the C. ocellifer population examined in the present study. On the other hand, termite availability does not seem to be greatly affected by the regional seasonal climate in other areas, as Teixeira-Filho et al. (2003) reported that Cnemidophorus littoralis Rocha, Araújo, Vrcibradic and Costa, 2000 consumed significant amounts of termites during both the rainy and dry seasons in a restinga area in Barra de Maricá (Rio de Janeiro State, Brazil) - demonstrating that this dietary resource is available all year long to widely foraging reptiles such as lizards of the family Teiidae (Pianka, 1966; 1970). Likewise, Vitt (1983) suggested that actively foraging lizards such as $C$. ocellifer tend to have continuous access to prey except during years of extreme drought. As such, the marked difference observed in the dietary composition of $C$. ocellifer in the present study as compared to conspecific populations at other sites seems to reflect more the influence of the quality of the habitat (vegetation cover and soil structure) on the availability of assemblages of termites and insect larvae than any greater preference of these lizards for orthopterans and coleopterans.

The high proportions of male and female lizards with empty stomachs would seem to indicate low availability of dietary resources for them in this environment (only seven prey categories were reported) and that these animals probably spend a great deal of time actively foraging. However, it is necessary to consider that the rate of prey consumption varies between actively foraging lizards and those that have adopted sit-and-wait strategies (Pianka, 1966; 1970; Huey and Pianka, 1981). To investigate this phenomenon, Huey et al. (2001) analysed the frequency of empty stomachs among different lizard families in Africa, Australia, and North, Central, and South America, and concluded that actively foraging lizards (such as the family Teiidae) have relatively greater frequencies of empty stomachs than lizards having a sit-and-wait foraging strategy.

In spite of the fact that male lizards where larger than females, there were no significant differences in the numbers of prey taken by both sexes, nor significant differences between the proportions of males and females with empty stomachs. These results indicate that the sampling method did not significantly influence the data about the diet of these lizards, and that the presence of larger numbers of males in the sample reflects the sex ratio of naturally occurring populations.

As the diets of the lizards were deduced from animals captured in pit-fall traps, it might be expected that these animals could eat any arthropods that had also fallen into the buckets. There was no firm evidence for this type of consumption, however, as a large number of captured lizards had empty stomachs and only low amounts of ingested prey were observed overall. Costa et al. (2008) reported in similar studies that no significant differences were observed between the stomach contents of lizards captured in pit-fall traps and those captured using other methods. These same authors argued that active foraging lizards (such as the three Cnemidophorus species they studied) can become stressed due to the limited freedom of movement in pit-fall traps and will not eat even if their natural prey is available.

The average SVL of sexually mature males and females of $C$. ocellifer in the reforested restinga area was observed to be notably smaller than that reported 
for a population of $C$. ocellifer encountered in Exú, Pernambuco State, in an area of dry caatinga vegetation (Vitt, 1983; Anderson and Vitt, 1990), indicating the existence of geographical variations in SVL among sexually mature populations.

Males of $C$. ocellifer reach sexual maturity with smaller SVL minimum dimensions than the females but attain maximum SVLs larger than those females. Depending on the locality sampled, the minimum size of $C$. ocellifer at sexual maturity may or may not vary between the two sexes (Vitt, 1983; Anderson and Vitt, 1990; Mesquita and Colli, 2003). Attaining early sexual maturity might increase the chances of an individual attaining greater reproductive success during its lifetime, although this early investment in sexual maturity will divert energy from growth (SVL) and body mass - and smaller males generally have less reproductive success due to their disadvantage in disputing with larger males for the females (Vitt, 1983; Anderson and Vitt, 1990).

Excluding the effect of size (SVL) from analyses of sexual dimorphism in the population of C. ocellifer studied here indicated that head size was also a dimorphic feature among these lizards. On the average, the heads of sexually mature males are longer, wider, and higher than those of the females. This phenomenon is commonly seen in other populations of C. ocellifer (Vitt, 1983; Vitt and Anderson, 1990; Mesquita and Colli, 2003). Vitt (1983) suggested that during antagonistic interactions with other males during their defense of rich foraging territories, males with larger heads tend to have an advantage over males with smaller heads - which will increase their access to females. As such, sexual dimorphism results from sexual selection (females choosing males with larger heads) (Vitt, 1983; Teixeira-Filho et al. 2003). The fact that no significant statistical differences were found between the body mass of males and females may be related to the storage condition of the material that was examined (measurements were performed on preserved lizards).

A tendency was noted for larger females to produce more eggs in the reforested restinga area, although the data was not actually statistically significant. The numbers of eggs produced in populations of $C$. ocellifer from other caatinga and cerrado regions were found to be related to the SVL of the females (Vitt, 1983; Anderson and Vitt, 1990; Mesquita and Colli, 2003). There is a general tendency for egg production to increase with the SVL of females, both between and within different lizard species (Fitch, 1970; Dunham et al., 1988). The simultaneous presence of eggs in the oviducts and in the vitelogenic follicles in some of the females examined here indicates the production of (at least) two clutches during the dry season. According to Trauth (1983), the production of multiple clutches in lizards can be determined by the presence of: i) concurrent vitellogenic ovarian follicles and oviductal eggs; ii) concurrent vitellogenic ovarian follicles and corpora lutea; iii) two distinct sets of corpora lutea, and iv) two (or more) distinct periods of weight loss (= ovipositioning) for a reproductively active female.

In summary, the low quality of the vegetation cover and the inadequate soil conditions in the youngest reforested restinga areas supposedly supports only a relatively depauperate arthropod fauna - which is reflected in the reduced variety of dietary items found in the stomachs of the specimens of $C$. ocellifer examined in the present study. As the sample size of lizards was relatively small, as was the number of stomachs containing any prey, it was not possible to compare the diets of the lizards from reforestation areas of different ages. It will be important in the future to investigate the effects of habitat quality on the period and duration of the daily activities of these lizards (thermoregulation and foraging), as well as their morphometric parameters (SVL, head size, and body mass) and their mean fat body mass and reproduction (variations in egg production and the availability of nesting sites).

Acknowledgements - The authors would like to thank the Graduate Program in Biological Sciences and the Conselho Nacional de Desenvolvimento Científico and Tecnológico (CNPq) for their financial support; as well as FUNCAP - Fundação Cearense de Apoio ao Desenvolvimento Científico and Tecnológico for the research grant (process 9913/06 - 0006-00) and productivity fellowship (process BPI0112-2.05/08) awarded to W. O. Almeida.

\section{References}

ANDERSON, RA. and VITT, LJ., 1990. Sexual selection versus alternative causes of sexual dimorphism in teiid lizards. Oecologia, vol. 90, p. 145-157

ARAUJO, DSD. and LACERDA, LD., 1987. A natureza das restingas. Ciência Hoje, vol. 6, no. 33, p. 42-48.

BERGALLO, HG. and ROCHA, CFD., 1994. Spatial and trophic niche differentiation in two sympatric lizards (Tropidurus torquatus and Cnemidophorus ocellifer) with different foraging tactics. Australian Journal of Ecology, vol. 19, p. 72-75.

COSTA, GC., MESQUITA, DO. and COLLI, GR., 2008. The effects of pitfall trapping on lizard diets. Journal of Herpetology, vol. 18 , p. $45-48$.

DIAS, EJR. and ROCHA, CFD., 2007. Niche differences between two sympatric whiptail (Cnemidophorus abaetensis and $C$. ocellifer, Teiidae) in the restinga habitat of Northeastern Brazil. Brazilian Journal of Biology, vol. 67, no. 1, p. 41-46.

DUNHAM, AE., MILES, DB. and REZNICK, DN., 1988. Life history patterns in squamate reptiles. In GANS, C. and HUEY, RB. (Eds.). Biology of the Reptilia. Vol. 16. Ecology B. Defense and Life History. New York: Alan R. Liss, Inc. p. 441-522.

FITCH, HS., 1970. Reproductive cycles in lizards and snakes. University of Kansas Museum of Natural History Publications, vol. 52, p. 1-247.

HUEY, RB. and PIANKA, ER., 1981. Ecological consequences of foraging mode. Ecology, vol. 62, no. 4, p. 991-999.

HUEY, RB., PIANKA, ER. and VITT, LJ., 2001. How often do lizards "Run on empty"? Ecology, vol. 82, no. 1, p. 1-7. 
LEE, KE. and WOOD, TG., 1971. Termites and soils. London: Academic Press, $251 \mathrm{p}$.

MAGNUSSON, ME. and SILVA, EV., 1993. Relative effects of size, season and species on the diets of some Amazonian Savanna lizards. Journal of Herpetology, vol. 27, no. 4, p. 380-385.

MAGNUSSON, ME., SILVA, EV. and LIMA, AP., 1987. Diet of Amazonian crocodilians. Journal of Herpetology, vol. 21, no. 2 , p. 85-95.

MAGNUSSON, WE., LIMA, AP., SILVA, WA. and ARAÚJO, MC., 2003. Use of geometric forms to estimate of invertebrates in ecological studies of dietary overlap. Copeia, vol. 2003, no. 1, p. 13-19.

MESQUITA, DO. and COLLI, GR., 2002. Geographic variation in the ecology of populations of some Brazilian species of Cnemidophorus (Squamata, Teiidae). Copeia, vol. 2002, no. 2, p. 285-298.

MESQUITA, DO. and COLLI, GR., 2003. The ecology of Cnemidophorus ocellifer (Squamata, Teiidae) in a Neotropical Savanna. Journal of Herpetology, vol. 37, no. 3, p. 498-509.

MENEZES, VA., ROCHA, CFD. and DUTRA, GF., 2004. Reproductive ecology of the parthenogenetic whiptail Lizard Cnemidophorus nativo in a Brazilian Restinga habitat. Journal of Herpetology, vol. 38, no. 2, p. 280-282.

MENEZES, VA., AMARAL, VC., SLUYS, MV. and ROCHA, CFD., 2006. Diet and foraging of the endemic lizard Cnemidophorus littoralis (Squamata, Teiidae) in the restinga de Jurubatiba, Macaé, RJ. Brazilian Journal of Biology, vol. 66, no. 3 , p. 803-807.

MILSTEAD, WW., 1965. Changes in competing population of whiptail lizards (Cnemidophorus) in Southwestern Texas. American Midland Naturalist, vol. 73, no. 1, p. 75-80.

OLIVEIRA-FILHO, AT. and CARVALHO, DA., 1993. Florística e fisionomia da vegetação no extremo norte do litoral da Paraíba. Revista Brasileira de Botânica, vol. 16, no. 1, p. $115-130$.

PIANKA, ER., 1970. Comparative autecology of the lizard Cnemidophorus tigris in different parts of its geographic range. Ecology, vol. 51, no. 4, p. 703-720.

PIANKA, ER., 1966. Convexity, desert lizards, and spatial heterogeneity. Ecology, vol. 47, p. 1055-1059.

POWELL, R., PARMERLEE, JS., RICE, MA. and SMITH, DD., 1990. Ecological observations on Hemidactylus brooki haitianus Meerwarth (Sauria: Gekkonidae) from Hispaniola. Caribbean Journal of Science, vol. 26, p. 67-70.

ROSADO, SCS., 2001. Revegetação de dunas degradadas no litoral norte da Paraíba. Available from: <http://www.cemacufla.com.br/trabalhospdf/palestras/palestra\%20rosado.pdf.>.

SHEPARD, DB., 2007. Habitat but not body shape affects predator attack frequency on lizard models in the Brazilian Cerrado. Herpetologica, vol. 63, no. 2, p. 193-202.

SUGUIO, K. and TESSLER, MG., 1984. Planícies de cordões litorâneos Quaternários do Brasil: origem e nomenclatura.
In LACERDA, LD., ARAÚJO, DSD., CERQUEIRA, R. and TURCO, B. (Orgs.). Restingas: origem, estrutura e processos. Niterói: J.L.D. Centro Editorial da Universidade Federal Fluminense. p. 15-26.

TAUBER, CA. and TAUBER, MJ., 1981. Insect seasonal cycle: genetics and evolution. Annual Review of Ecology and Systematics, vol. 12, no. 1981, p. 281-308.

TEIXEIRA-FILHO, PF., ROCHA, CFD. and RIBAS, SC., 2003. Relative feeding specialization may depress ontogenetic, seasonal, and sexual variations in diet: the endemic lizard Cnemidophorus littoralis (Teiidae). Brazilian Journal of Biology, vol. 63 , no. 2, p. 321-328.

TRAUTH, SE., 1983. Nesting habitat and reproductive characteristics of the lizard Cnemidophorus sexlineatus (Lacertilia: Teiidae). American Midland Naturalist, vol. 109, no. 2, p. 289-299.

VASCONCELLOS, A., MÉLO, ACS., VASCONCELLOSSEGUNDO, EM. and BANDEIRA, AG., 2005. Cupins de duas florestas de restinga do nordeste brasileiro. Iheringia. Serie Zoologia, vol. 95, no. 2, p. 127-131.

VANZOLINI, PE., RAMOS-COSTA, AM. and VITT, LJ., 1980. Répteis das caatingas. Rio de Janeiro: Academia Brasileira de Ciência, 161p.

VITT, LJ., 1983. Reproductive and sexual dimorphism in the tropical teiid lizard Cnemidophorus ocellifer. Copeia, vol. 1983, no. 2, p. 359-366.

,1991. An introduction to the ecology of Cerrado lizards. Journal of Herpetology, vol. 25, no. 1, p. 79-90.

,1995. The ecology of tropical lizards in the Caatinga of Northeast Brazil. Occasional Papers of the Oklahoma Museum of Natural History, no. 1, p. 1-29.

VITT, LJ. and CARVALHO, CM., 1995. Niche partitioning in a tropical wet season: lizards in the Lavrado area of Northern Brazil. Copeia, vol. 1995, no. 2, p. 305-329.

VITT, LJ. and COLLI, GR., 1994. Geographical ecology of a Neotropical lizard: Ameiva ameiva (Teiidae) in Brazil. Canadian journal of zoology, vol. 72, p. 1986-2008.

VITT, LJ., ZANI, PA. and BARROS, AAM., 1997. Ecological variation among populations of the gekkonid lizard Gonatodes humeralis in the Amazon Basin. Copeia, vol. 1997, no. 1, p. 32-43.

VRCIBRADIC, D. and ROCHA, CFD., 1996. Ecological differences in tropical sympatric skinks (Mabuya macrorhyncha and Mabuya agilis) in Southwestern Brazil. Journal of Herpetology, vol. 30, no. 1, p. 60-67.

ZEPPELINI, D., BELLINI, BC., CREÃO-DUARTE, AJ. and HERNÁNDEZ, MIM., 2008. Collembola as bioindicators of restoration in mined sand dunes of Northeastern Brazil. Biodiversity and Conservation, vol. 18, no. 5, p. 1161-1170.

WOLDA, H., 1988. Insect seasonality: why? Annual Review of Ecology and Systematics, vol. 19, no. 1988, p. 1-18. 
Appendix. List of examined material:

UFPB 4798, UFPB 4799, UFPB 4800, UFPB 4801, UFPB 4802, UFPB 4803, UFPB 4804, UFPB 4805, UFPB 4806, UFPB 4807, UFPB 4808, UFPB 4809, UFPB 4810, UFPB 4811, UFPB 4812, UFPB 4813, UFPB 4815, UFPB 4816, UFPB 4817, UFPB 4819, UFPB 4820, UFPB 4821, UFPB 4822, UFPB 4823, UFPB 4824, UFPB 4825, UFPB 4826, UFPB 4827, UFPB 4828, UFPB 4829, UFPB 4830, UFPB 4831, UFPB 4832, UFPB 4833, UFPB 4834, UFPB 4835, UFPB 4836, UFPB 4837, UFPB 4838, UFPB 4839, UFPB 4840, UFPB 4841, UFPB 4842, UFPB 4843, UFPB 4844, UFPB 4845, UFPB 4846, UFPB 4847, UFPB 4848, UFPB 4849, UFPB 4850, UFPB 4851, UFPB 4852, UFPB 4853, UFPB 4854, UFPB 4855, UFPB 4856, UFPB 4857, UFPB 4858, UFPB 4859, UFPB 4860, UFPB 4861, UFPB 4862, UFPB 4863, UFPB 4864, UFPB 4866, UFPB 4867, UFPB 4868, UFPB 4869, UFPB 4870, UFPB 4871, UFPB 4872, UFPB 4873, UFPB 4874 e UFPB 4875. 